\title{
Prevalence of Allergic Sensitization in Childhood Asthma
}

Bijay Kumar Meher ${ }^{1}$, Deepti D. Pradhan ${ }^{2}$, Jatadhari Mahar ${ }^{3}$, Sanjay K. Sahu ${ }^{2}$

1. Pediatrics, Bhima Bhoi Medical College and Hospital, Balangir, IND 2. Pediatrics, Kalinga Institute of Medical Sciences, Bhubaneswar, IND 3. Pediatrics, Srirama Chandra Bhanja (SCB) Medical College and Hospital, Cuttack, IND

Corresponding author: Bijay Kumar Meher, bkmeher18711@gmail.com

\section{Abstract \\ Introduction}

The allergic sensitization in childhood asthma is common and the prevalence varies in different geographical locations. The data on allergen sensitization to guide clinicians on allergy avoidance is limited.

\section{Method}

This prospective observational study was conducted between October 2019 and April 2020 on children aged two to 14 years attending an outpatient clinic. Those with recurrent wheezing or physician-diagnosed asthma were interviewed; eosinophil count, total serum immunoglobulin E (IgE) was measured; and skin prick test (SPT) was done using standardized reagents. Wheal size of $\geqslant 3 \mathrm{~mm}$ was considered positive.

\section{Results}

A total of 80 children were enrolled. The mean age was $71.15 \pm 33.52$ months (M:F ratio $=1.96: 1$ ). Allergic rhinitis, conjunctivitis, and dermatosis were seen in 76 (95.0\%), 33 (41.3\%), and 22 (27.5\%) cases, respectively. The mean absolute eosinophil count was $576 \pm 427$ per $\mathrm{cmm}$. The mean total IgE was $800.9 \pm$ $883.2 \mathrm{IU} / \mathrm{ml}$. Seasonal and diurnal variations were found in 34 (42.5\%) and 79 (98.8\%) cases. Out of 1753 skin pricks using 27 reagents, 355 (20.25\%) were positive. Increasing age was significantly associated with increasing SPT positivity $(\mathrm{P}=0.0001)$. The most common sensitive aeroallergens were Kentucky bluegrass (25\%), Dermatophagoides pteronyssinus (22.5\%), Dermatophagoides farinae (21.3\%), Timothy grass, and Alternaria alternans (20\% each). The most common sensitive food allergens were spinach (25\%), banana (22.5\%), carp (20\%), shrimp and hen's egg (18.8\% each), and cow's milk (17.5\%).

\section{Conclusion}

Increasing age was associated with increasing SPT positivity in childhood asthma. The most common sensitive aeroallergens were Kentucky bluegrass and Dermatophagoides pteronyssinus; spinach and banana were the most common food allergen.

Review began 05/18/2021 Review ended 05/21/2021 Published 05/29/2021

\section{() Copyright 2021}

Meher et al. This is an open access article distributed under the terms of the Creative Commons Attribution License CC-BY 4.0., which permits unrestricted use, distribution, and reproduction in any medium, provided the original author and source are credited.
Categories: Family/General Practice, Pediatrics, Allergy/Immunology

Keywords: asthma, allergic rhinitis, immunoglobulin e, skin prick test, recurrent wheezing

\section{Introduction}

Asthma is a heterogeneous disease, defined by the recurrent episodes of wheeze, shortness of breath, chest tightness, and cough that vary over time and intensity, together with variable expiratory airflow limitation [1]. Its prevalence is around 5-10\% worldwide [2,3]. The diagnosis is based on characteristic symptom patterns, i.e., $\geqslant 3$ episodes of wheezing over a 12-month period [4]. Atopy, a genetic predisposition to produce an excess amount of immunoglobulin E (IgE) antibodies when exposed to allergens is nearly a universal finding in children with asthma $[5,6]$. Allergic sensitization is a hypersensitivity reaction to a particular antigen, which can be assessed by in-vivo demonstration of bound IgE and mast cell degranulation by skin prick testing (SPT) or in-vitro tests to detect the production of free IgE to a specific allergen (SIgE) [7]. Allergic sensitization using SPT is not a routine practice and sensitization data on childhood asthma in India are scarce [8]. The present study was designed to find out the prevalence of atopy and allergy in childhood asthma by estimation of serum total IgE assay and to find out the spectrum of allergic sensitization to commonly selected aeroallergen and food allergen using SPT.

\section{Materials And Methods}

This was an observational study carried out in Kid's first outpatient clinic, Cuttack, an eastern city of Odisha state from October 2019 to April 2020. Approval was obtained from the institutional ethical committee, Balangir. Informed consent was obtained from the parents for enrolling children in this study. Children of age two to 14 years diagnosed with asthma (Global Initiative for Asthma \{GINA\} guidelines for diagnostic criteria of asthma in children) or have a history of recurrent ( $\geqslant 3$ in the last 12 months) episodes of 
respiratory symptoms, such as wheezing, shortness of breath, chest tightness, and cough were included in the study. Seriously ill children requiring hospitalization and children with features suggestive of alternative diagnosis were excluded [9]. A sample size of 80 was calculated with a power of 0.81 for a $5 \%$ level of significance.

Demographic data like age, sex, socioeconomic status, anthropometric details, associated features of allergic rhinitis (AR), allergic conjunctivitis (AC), and allergic dermatosis (AD) were observed. AR was diagnosed with a history of nasal congestion, rhinorrhea, and itching often accompanied by sneezing. AC was diagnosed with ocular itching, tearing with injected or swollen conjunctiva. AD was diagnosed on the basis of the presence of pruritus, eczematous dermatitis with a chronic or relapsing course. A detailed history regarding seasonal variation, diurnal variation, location of symptoms (indoor/outdoor), and possible triggers was collected. Seasonal variation is the variation in a time series within a year that is repeated more or less regularly. Diurnal variation refers to the presence of symptoms that occur at a particular time of the day (e.g., during sleep) or even when symptoms occur throughout the day, worse at some time (e.g., night). Serum total IgE and blood eosinophil count were measured. IgE level was compared with the agespecific reference range as described by Barbee et al. and Kjellman et al. [10,11]. The patients' management was done as per the GINA guidelines [1].

\section{Skin prick test}

SPT was conducted after control of acute phase using Allergo SPT Kit (Merck Pharma, USA) with the available reagents selecting common allergens from different groups (dust mite, mold, grass and weed pollen, animal epithelia, foods like cow's milk, hen's egg, wheat, peanut, meat, seafood, fruits, and vegetables). In order to ascertain individual reactivity, control tests with buffered saline (negative control) and histamine (positive control) were carried out.

One week before performing SPT, oral drugs including antihistamines, steroids, or any other drugs likely to affect SPT were discontinued but inhaled drugs were continued. But the cases, in those who were administered long-acting antihistamines, SPT was performed after four weeks of discontinuation of the drug. Twenty-seven different types of standardized allergens were selected, which included dust mite (two types), mold (four types), grass pollen (four types), weed pollen (three types), animal epithelia (one type), and food antigen (13 types). SPT was conducted by putting a drop of antigen on the healthy skin over volar aspects of both forearms ( $5 \mathrm{~cm}$ away from the wrist and $3 \mathrm{~cm}$ from antecubital fossa) with a dropper pipette at a gap of approximately $4 \mathrm{~cm}$ between the drops. A shallow prick was made using the tip of a specially designed "lancet" through the drop of the test solution at $45^{\circ}$ to $60^{\circ}$ angle to the skin. The lancet was lifted slightly so that a small amount of test solution can penetrate the skin underneath the tip. Reading was interpreted after a lapse of 15-20 minutes. Skin reactivity was assessed by calculating the mean diameter against a scale provided with the kit. To establish test validity, positive control needed to be at least $3 \mathrm{~mm}$ more than the negative control. Any reaction with normal saline more than $3 \mathrm{~mm}$ was considered invalid. A positive result to a specific antigen was indicated by a wheal diameter measuring $\geqslant 3 \mathrm{~mm}$. Wheal diameter $<3 \mathrm{~mm}$ or less than negative control was taken as normal.

\section{Sample size}

The chi-square test of association and the Mann-Whitney test are used in this analysis. The sample size used here was 80 . For the chi-square test, this sample size achieved a power of 0.81 for $5 \%$ level of significance considering a medium effect size of 0.32 and 1 degree of freedom. This was computed using posthoc computed achieved power analysis using G. Power 3.2 software [12].

\section{Statistical methods}

The analysis was carried out using IBM SPSS Statistics 24.0 software (New York, USA: IBM Corp.). Descriptive statistics were calculated. The P-value $<0.05$ was considered statistically significant. For categorical variables, the test of independence was studied using cross-tabulation procedure and chi-square test of association. Frequency procedure was used to find out the distribution of demographic characteristics of the sample and allergic sensitization in the skin prick test. For scale variable comparison of two distributions was done using mean and standard deviation, median and interquartile range (IQR), and Mann-Whitney test.

\section{Results}

The sample cases of 80 children with asthma had a mean (SD) age of 71.15 (33.52) months and an M:F ratio of 1.96:1. AR, AC, and AD were associated in 76 (95.0\%), 33 (41.3\%), and 22 (27.5\%) cases, respectively. The mean (SD) absolute eosinophil count was 576.1 (427.5) per $\mathrm{cmm}$. Total serum IgE $>150 \mathrm{IU} / \mathrm{ml}$ was found in 64 $(82.5 \%)$ children. The mean (SD) total IgE was 800.9 (883.2) IU/ml. Seasonal variation and diurnal variations were found in 34 (42.5\%) and 79 (98.8\%) cases. Indoor was the major location for the symptoms. Important triggering agents for wheezing reported by parents were found out to be "sleeping/lying in bed'" and "exercise" in 23 (31.9\%) and 7 (9.7\%), respectively (Table 1). 


\section{Cureus}

\begin{tabular}{|c|c|}
\hline Variable & P-value \\
\hline Sex (M:F) & 1.96:1 \\
\hline Age $^{*}$ (month) & 71.15 (33.52) \\
\hline \multicolumn{2}{|l|}{ Residence } \\
\hline Rural & $26(32.5)$ \\
\hline Urban & $54(67.5)$ \\
\hline $\mathrm{BMI}^{*}\left(\mathrm{~kg} / \mathrm{m}^{2}\right)$ & $17.4(3.7)$ \\
\hline \multicolumn{2}{|l|}{ Associated features } \\
\hline Allergic rhinitis & $76(95.0)$ \\
\hline Allergic conjunctivitis & $33(41.3)$ \\
\hline Allergic dermatitis & $22(27.5)$ \\
\hline Eosinophil count ${ }^{*}(\%)$ & $5.26(3.11)$ \\
\hline Absolute eosinophil count* ${ }^{\star}$ per cmm) & $576.1(427.5)$ \\
\hline Total IgE* (IU/ml) & 800.9 (883.2) \\
\hline Total lgE $\mathrm{E}^{\star \star}(\mathrm{IU} / \mathrm{ml})$ & $435.5(245.8,1044.8)$ \\
\hline $\operatorname{lgE}>150 \mathrm{lU} / \mathrm{ml}$ & $64(82.5)$ \\
\hline Diurnal variation present & $79(98.8)$ \\
\hline Seasonal variation present & 34 (42.5) \\
\hline \multicolumn{2}{|l|}{ Symptom location } \\
\hline Indoor & $43(53.8)$ \\
\hline Outdoor & $23(28.7)$ \\
\hline Both (indoor and outdoor) & $9(11.3)$ \\
\hline \multicolumn{2}{|l|}{ Triggers } \\
\hline Walking in a garden & $1(1.4)$ \\
\hline Sleeping/lying in bed & $23(31.9)$ \\
\hline Exposure to animals/pets & $1(1.4)$ \\
\hline Dust/dusty atmosphere & $5(6.9)$ \\
\hline Consumption of particular foods & $1(1.4)$ \\
\hline Physical exertion/exercise & $7(9.7)$ \\
\hline
\end{tabular}

\section{TABLE 1: Baseline characteristics of children with asthma $(n=80)$}

Data presented as $\mathrm{n}(\%)$.

*Mean (SD).

**Median (IQR).

IgE, immunoglobulin E; M, male; F, female

Figure 1 depicts the allergic sensitization in SPT in children with asthma. The most common sensitive aeroallergens were Kentucky bluegrass (25\%), Dermatophagoides pteronyssinus (22.5\%), Dermatophagoides farinae (21.3\%), Timothy grass, and Alternaria alternans (20\% each). The most common sensitive food 


\section{Cureus}

allergens were spinach (25\%), banana (22.5\%), carp (20\%), shrimp and hen's egg (18.8\% each), and cow’s milk (17.5\%).

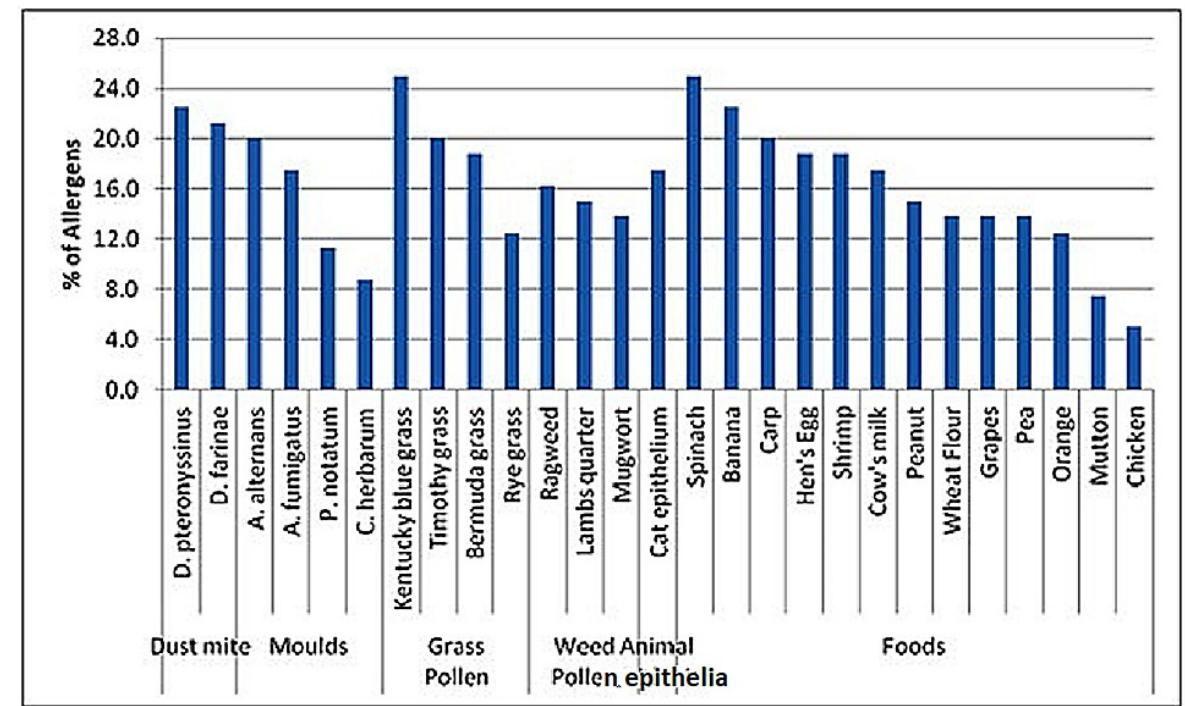

FIGURE 1: Prevalence of different aeroallergen and food allergen sensitization in childhood asthma

Table 2 and Figure 2 compare the age and sex distribution of overall SPT positivity. Twenty-seven reagents were tested and out of 1753 skin pricks, $355(20.25 \%)$ tests were positive. The increase in age is significantly associated with the increase in SPT positivity $(\mathrm{P}=0.000)$. Overall, there is no significant association between SPT positivity and gender.

\begin{tabular}{|c|c|c|c|}
\hline Factors & Total & SPT positivity & P-value \\
\hline \multicolumn{4}{|c|}{ Age (year) } \\
\hline $2-4$ & 876 & $143(16.3 \%)$ & \multirow{3}{*}{0.000} \\
\hline $5-9$ & 716 & $161(22.5 \%)$ & \\
\hline$\geq 10$ & 161 & 51 (31.7\%) & \\
\hline \multicolumn{4}{|l|}{ Sex } \\
\hline Male & 1162 & 237 (20.4) & \multirow{2}{*}{0.832} \\
\hline Female & 591 & $118(20.0)$ & \\
\hline
\end{tabular}

TABLE 2: Age and sex distribution of SPT positivity against different allergen groups Data presented as $\mathrm{n}(\%)$. 


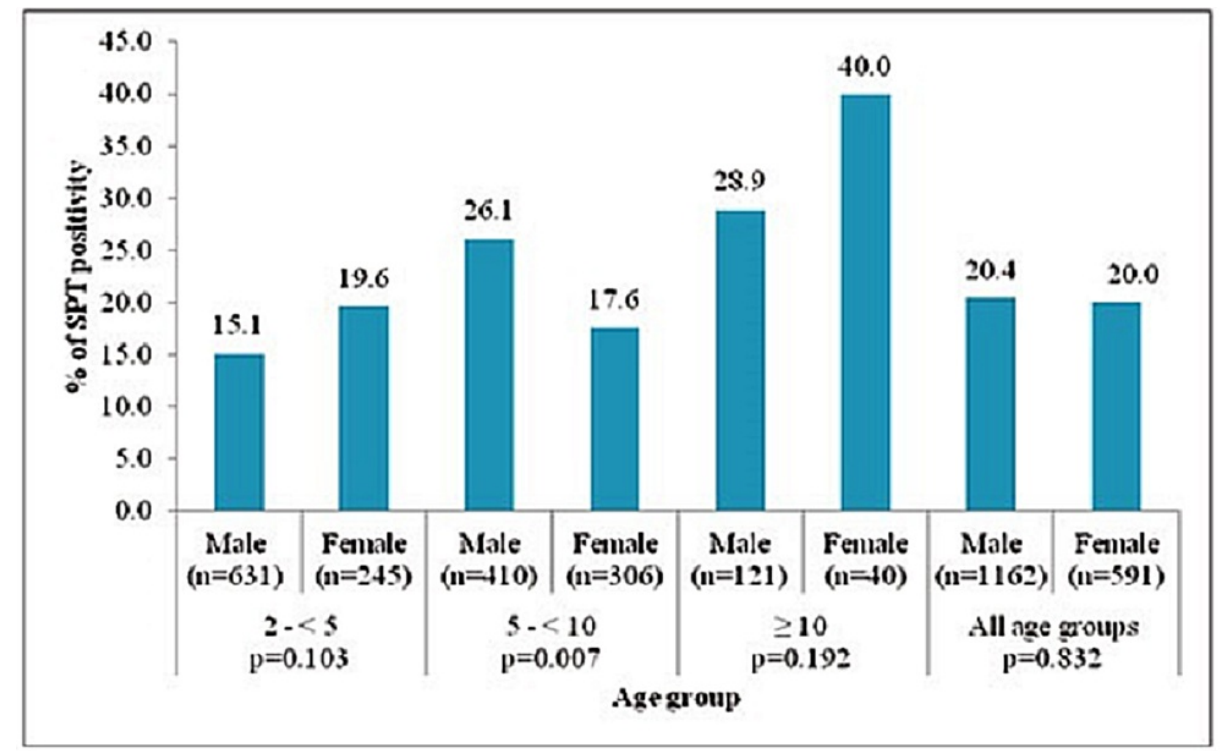

FIGURE 2: Age and sex distribution of SPT positivity against different allergen groups.

SPT, skin prick test

Table 3 shows the demographic characteristics and associated features of asthmatic children with different allergen sensitization. Dust mite and mold sensitization are found significantly more in older children compared to younger children ( $\mathrm{P}=0.045$ and 0.026 , respectively). There is no significant association of sensitivity of different allergen with gender, habitat, and BMI. Association of AR, AC, and AD are similar in different allergen sensitized groups. There is no significant difference with respect to eosinophil count, total serum IgE, seasonal and diurnal variation between different groups of allergen sensitization.

\begin{tabular}{|c|c|c|c|c|c|c|}
\hline Variable & Characteristics/sensitization & $\begin{array}{l}\text { Dust mites } \\
\text { (+ve 22, -ve } \\
58 \text { ) }\end{array}$ & $\begin{array}{l}\text { Mold (+ve } \\
36,- \text { ve 44) }\end{array}$ & $\begin{array}{l}\text { Grass pollen } \\
\text { (+ve } 43,- \text { ve } 37 \text { ) }\end{array}$ & $\begin{array}{l}\text { Weed pollen } \\
\text { (+ve } 27 \text {, -ve } 53 \text { ) }\end{array}$ & $\begin{array}{l}\text { Foods (+ve } \\
65, \text {-ve 15) }\end{array}$ \\
\hline \multirow{3}{*}{ Sex } & Male $(n=53)$ & $15(28.3)$ & $22(41.5)$ & $32(60.4)$ & $18(34.0)$ & $43(81.1)$ \\
\hline & Female $(n=27)$ & $7(25.9)$ & $14(51.9)$ & $11(40.7)$ & $9(33.3)$ & $22(81.5)$ \\
\hline & P-value ${ }^{*}$ & 0.822 & 0.379 & 0.096 & 0.955 & 0.970 \\
\hline \multirow{4}{*}{ Age $^{\star \star}$ (year) } & $2-4(n=39)$ & $6(15.4)$ & $12(30.8)$ & 19 (48.7) & $11(28.2)$ & $32(82.1)$ \\
\hline & $5-9(n=33)$ & $12(36.4)$ & $18(54.5)$ & $21(63.6)$ & $12(36.4)$ & $25(75.8)$ \\
\hline & $\geq 10(n=8)$ & $4(50.0)$ & $6(75.0)$ & $3(37.5)$ & $4(50.0)$ & $8(100)$ \\
\hline & P-value & 0.045 & 0.026 & 0.280 & 0.453 & 0.284 \\
\hline \multirow{3}{*}{ Habitat } & Rural & $7(26.9)$ & $12(46.2)$ & $17(65.4)$ & $12(46.2)$ & $23(88.5)$ \\
\hline & Urban & $15(27.8)$ & $24(44.4)$ & $26(48.1)$ & $15(27.8)$ & $42(77.8)$ \\
\hline & P-value ${ }^{*}$ & 0.936 & 0.886 & 0.148 & 0.104 & 0.252 \\
\hline \multirow{3}{*}{$\operatorname{BMI}^{\star \star}\left(\mathrm{kg} / \mathrm{m}^{2}\right)$} & SPT +ve & $18.2(4.2)$ & $18.2(4.3)$ & $17.1(3.2)$ & $17.4(3.3)$ & $17.4(3.7)$ \\
\hline & SPT -ve & $17.1(3.5)$ & 16.9 (3.0) & $17.8(4.2)$ & 17.4 (3.9) & 17.5 (3.7) \\
\hline & $P$-value & 0.301 & 0.230 & 0.647 & 0.768 & 0.921 \\
\hline \multirow[b]{2}{*}{ AR $(n=76)$} & SPT +ve & $21(95.5)$ & $33(91.7)$ & $41(95.3)$ & $25(92.6)$ & $61(93.8)$ \\
\hline & SPI -ve & $55(94.8)$ & $43(97.7)$ & $35(94.6)$ & 51 (96.2) & $15(100.0)$ \\
\hline
\end{tabular}




\begin{tabular}{|c|c|c|c|c|c|c|}
\hline & P-value ${ }^{*}$ & 0.909 & 0.216 & 0.877 & 0.481 & 0.324 \\
\hline \multirow{3}{*}{ AC $(n=33)$} & SPT +ve & $11(50.0)$ & $15(41.7)$ & 16 (37.2) & $10(37.0)$ & 25 (38.5) \\
\hline & SPT -ve & $22(37.9)$ & $18(40.9)$ & $17(45.9)$ & 23 (43.4) & $8(53.3)$ \\
\hline & P-value ${ }^{*}$ & 0.328 & 0.945 & 0.429 & 0.585 & 0.292 \\
\hline \multirow{3}{*}{$A D(n=22)$} & SPT +ve & $8(36.4)$ & 7 (19.4) & 15 (34.9) & $6(22.2)$ & $18(27.7)$ \\
\hline & SPT -ve & $14(24.1)$ & 15 (34.1) & $7(18.9)$ & $16(30.2)$ & $4(26.7)$ \\
\hline & P-value ${ }^{*}$ & 0.274 & 0.144 & 0.111 & 0.451 & 0.936 \\
\hline \multirow{3}{*}{$\begin{array}{l}\text { Eosinophil } \\
\text { count }^{\star \star}(\%)\end{array}$} & SPT +ve & $5.8(2.9)$ & $5.4(3.0)$ & $4.9(2.2)$ & $4.8(2.7)$ & $5.2(3.0)$ \\
\hline & SPT -ve & $5.1(3.2)$ & $5.2(3.3)$ & $5.8(3.9)$ & $5.6(3.3)$ & $5.4(3.8)$ \\
\hline & P-value & 0.208 & 0.621 & 0.711 & 0.419 & 0.789 \\
\hline \multirow{3}{*}{$\begin{array}{l}\text { AEC (per } \\
\mathrm{cmm} \text { ) }\end{array}$} & SPT +ve & 572.09 (272.4) & $\begin{array}{l}534.7 \\
(287.2)\end{array}$ & $517.8(250.1)$ & $510.7(313.8)$ & 572.2 (440.5) \\
\hline & SPT -ve & $577.7(475.3)$ & $\begin{array}{l}610.0 \\
(515.8)\end{array}$ & $643.1(565.1)$ & $609.4(474.4)$ & 593.0 (379.6) \\
\hline & P-value & 0.265 & 0.942 & 0.696 & 0.545 & 0.902 \\
\hline \multirow{3}{*}{$\begin{array}{l}\text { Total IgE" } \\
\text { (IU/ml) }\end{array}$} & SPT +ve & 1118.9 (1096.6) & $\begin{array}{l}902.4 \\
(1014.9)\end{array}$ & 799.9 (874.3) & $727.0(836.1)$ & 759.3 (812.8) \\
\hline & SPT -ve & $680.3(764.3)$ & $\begin{array}{l}717.9 \\
(760.9)\end{array}$ & $802.1(905.5)$ & $838.6(911.7)$ & $\begin{array}{l}981.3 \\
(1157.0)\end{array}$ \\
\hline & $P$-value $e^{\star \star \star}$ & 0.071 & 0.820 & 0.559 & 0.915 & 0.786 \\
\hline
\end{tabular}

TABLE 3: Demographic characteristics and associated features of asthmatic children with different groups of allergen sensitization

Data presented as n (\%).

${ }^{*}$ Chi-square test.

**Mean (SD).

***Mann-Whitney test.

AR, allergic rhinitis; AC, allergic conjunctivitis; AD, atopic dermatitis; IgE, immunoglobulin E; AEC, absolute eosinophil count; SPT, skin prick test

Table 4 shows the demographic characteristics and associated features of asthmatic children with different food allergen sensitization. Cow's milk allergy is seen more in females compared to males ( $37 \%$ vs $7.5 \%, \mathrm{P}=$ 0.001). A higher prevalence of food allergen sensitization is found with increasing age; statistically significant with cow's milk, peanut, meat, and seafood group $(\mathrm{P}=0.037,0.009,0.020$, respectively). The association of $\mathrm{AR}, \mathrm{AC}$, and $\mathrm{AD}$ is similar in different groups of food allergen sensitization. There is no significant difference with respect to eosinophil count, total serum IgE, seasonal and diurnal variation between different groups of food allergen sensitization (Table 4).

\begin{tabular}{|c|c|c|c|c|c|c|c|}
\hline Variable & $\begin{array}{l}\text { Characteristics/ } \\
\text { sensitization }\end{array}$ & $\begin{array}{l}\text { Cow's milk } \\
\text { (+ve 14, -ve } \\
66)\end{array}$ & $\begin{array}{l}\text { Hen's egg } \\
\text { (+ve 15, -ve } \\
65)\end{array}$ & $\begin{array}{l}\text { Peanut } \\
\text { (+ve 12, -ve } \\
68 \text { ) }\end{array}$ & $\begin{array}{l}\text { Wheat flour } \\
\text { (+ve 11, -ve } \\
69 \text { ) }\end{array}$ & $\begin{array}{l}\text { Meat and } \\
\text { seafood (+ve } 34,- \\
\text { ve } 46 \text { ) }\end{array}$ & $\begin{array}{l}\text { Fruits and veg. } \\
\text { (+ve } 42,- \text { ve } 38 \text { ) }\end{array}$ \\
\hline \multirow{3}{*}{ Sex } & Male $(n=53)$ & $4(7.5)$ & $11(20.8)$ & 7 (13.2) & 7 (13.2) & $26(49.1)$ & $26(49.1)$ \\
\hline & Female $(n=27)$ & $10(37.0)$ & 4 (14.8) & 5 (18.5) & $4(14.8)$ & $8(29.6)$ & $16(59.3)$ \\
\hline & P-value ${ }^{*}$ & 0.001 & 0.520 & 0.529 & 0.844 & 0.096 & 0.388 \\
\hline & $2-4(n=39)$ & 5 (12.8) & 5 (12.8) & $3(7.7)$ & 6 (15.4) & $21(53.8)$ & 21 (53.8) \\
\hline
\end{tabular}




\begin{tabular}{|c|c|c|c|c|c|c|c|}
\hline \multirow{3}{*}{ Age (year) } & $5-9(n=33)$ & $5(15.2)$ & $7(21.2)$ & $5(15.2)$ & 4 (12.1) & $8(24.2)$ & 17 (51.5) \\
\hline & $\geq 10(n=8)$ & $4(50.0)$ & $3(37.5)$ & $4(50.0)$ & 1 (12.5) & $5(62.5)$ & $4(50.0)$ \\
\hline & P-value ${ }^{*}$ & 0.037 & 0.237 & 0.009 & 0.917 & 0.020 & 0.970 \\
\hline \multirow{3}{*}{ Habitat } & Rural $(n=26)$ & $5(19.2)$ & $4(15.4)$ & $6(23.1)$ & $3(11.5)$ & 12 (46.2) & $15(57.7)$ \\
\hline & Urban $(n=54)$ & $9(16.7)$ & $11(20.4)$ & $6(11.1)$ & $8(14.8)$ & $22(40.7)$ & $27(50.0)$ \\
\hline & P-value & 0.777 & 0.593 & 0.160 & 0.690 & 0.646 & 0.519 \\
\hline \multirow{3}{*}{$\begin{array}{l}B M I^{* *} \\
\left(\mathrm{~kg} / \mathrm{m}^{2}\right)\end{array}$} & SPT +ve & 18.4 (3.8) & 18.2 (3.2) & 18.4 (3.8) & $18.1(4.0)$ & $17.6(3.8)$ & $17.1(3.3)$ \\
\hline & SPT -ve & $17.2(3.7)$ & $17.3(3.8)$ & $17.2(3.7)$ & $17.3(3.7)$ & $17.3(3.7)$ & $17.8(4.1)$ \\
\hline & $P$-value & 0.186 & 0.147 & 0.241 & 0.463 & 0.665 & 0.600 \\
\hline \multirow{3}{*}{$A R(n=76)$} & SPT +ve & 13 (92.9) & 14 (93.3) & $11(91.7)$ & $10(90.9)$ & $33(97.1)$ & $40(95.2)$ \\
\hline & SPT -ve & $63(95.5)$ & 62 (95.4\%) & 65 (95.6) & 66 (95.7) & $43(93.5)$ & $36(94.7)$ \\
\hline & P-value ${ }^{*}$ & 0.685 & 0.742 & 0.566 & 0.503 & 0.468 & 0.918 \\
\hline \multirow{3}{*}{$A C(n=33)$} & SPT +ve & $7(50.0)$ & $5(33.3)$ & $7(58.3)$ & $3(27.3)$ & $12(35.3)$ & $13(31.0)$ \\
\hline & SPT -ve & $26(39.4)$ & $28(43.1)$ & $26(38.2)$ & $30(43.5)$ & $21(45.7)$ & $20(52.6)$ \\
\hline & $P$-value ${ }^{*}$ & 0.464 & 0.490 & 0.831 & 0.311 & 0.352 & 0.049 \\
\hline \multirow{3}{*}{$A D(n=22)$} & SPT +ve & $2(14.3)$ & $7(46.7)$ & $2(16.7)$ & $4(36.4)$ & $11(32.4)$ & $13(31.0)$ \\
\hline & SPI -ve & $20(30.3)$ & $15(23.1)$ & $20(29.4)$ & $18(26.1)$ & $11(23.9)$ & $9(23.7)$ \\
\hline & P-value & 0.223 & 0.065 & 0.362 & 0.478 & 0.403 & 0.467 \\
\hline \multirow{3}{*}{$\begin{array}{l}\text { Eosinophil } \\
\text { count }^{\star *}(\%)\end{array}$} & SPI +ve & $6.0(4.2)$ & $5.6(3.4)$ & $4.5(1.3)$ & $4.1(1.4)$ & $5.4(2.4)$ & $4.9(2.4)$ \\
\hline & SPT -ve & $5.1(2.9)$ & $5.2(3.1)$ & $5.4(3.3)$ & $5.4(3.3)$ & $5.2(3.4)$ & $5.8(3.8)$ \\
\hline & P-value & 0.626 & 0.955 & 0.668 & 0.219 & 0.301 & 0.504 \\
\hline \multirow{3}{*}{$\begin{array}{l}\text { AEC (per } \\
\text { cmm) }\end{array}$} & SPT +ve & 679.1 (753.9) & $563.1(351.7)$ & $\begin{array}{l}460.3 \\
(110.0)\end{array}$ & 446.4 (183.5) & $570.6(308.5)$ & $500.4(271.8)$ \\
\hline & SPT -ve & $554.2(325.1)$ & $579.1(445.5)$ & $\begin{array}{l}596.5 \\
(459.1)\end{array}$ & $596.8(451.9)$ & $580.2(501.1)$ & $659.8(542.8)$ \\
\hline & P-value ${ }^{\star \star \star}$ & 0.990 & 0.853 & 0.415 & 0.288 & 0.471 & 0.365 \\
\hline \multirow{3}{*}{$\begin{array}{l}\text { Total lgE } \\
\text { (IU/ml) }\end{array}$} & SPI +ve & $949.9(822.2)$ & 739.4 (1016.1) & $\begin{array}{l}825.8 \\
(661.3)\end{array}$ & $263.9(240.5)$ & $800.1(814.4)$ & $705.3(816.8)$ \\
\hline & SPT -ve & $769.3(898.3)$ & $815.1(857.8)$ & $\begin{array}{l}796.5 \\
(920.7)\end{array}$ & $886.5(918.5)$ & $801.5(939.7)$ & $906.6(950.9)$ \\
\hline & $P$-value & 0.175 & 0.398 & 0.377 & 0.010 & 0.903 & 0.223 \\
\hline
\end{tabular}

TABLE 4: Demographic characteristics and associated features of asthmatic children with different groups of food allergen sensitization

Data presented as $\mathrm{n}(\%)$.

${ }^{\star}$ Chi-square test.

${ }^{\star *}$ Mean (SD).

*** Mann-Whitney test.

AR, allergic rhinitis; AD, atopic dermatitis; IgE, immunoglobulin E; AEC, absolute eosinophil count; SPT, skin prick test 


\section{Discussion}

In the present study, children with asthma were assessed for associated atopy, IgE assay, and skin prick tests to identify IgE-mediated allergen sensitization. History taking and documentation of temporal association to identify allergen were difficult to predict an allergen responsible for wheezing attacks in these children.

The majority ( $\mathrm{n}=56,80 \%$ ) cases showed IgE level $>150 \mathrm{IU} / \mathrm{ml}$, and the mean total IgE was $800.9 \pm 883.2 \mathrm{IU} / \mathrm{ml}$. This is similar to the study by Rathoria et al. who reported the mean IgE levels in childhood asthma to be 881.81IU/ml [13]. This is consistent with previous reports suggesting serum IgE be characteristics of most allergic diseases including asthma [14-16]. Further, raised levels are neither sensitive nor specific for allergy diagnosis and documented in different conditions like a parasitic infestation, immunodeficiency disorders, Epstein-Barr virus infection, rheumatoid arthritis [17,18]. Other atopic manifestations like AR, AC, and $\mathrm{AD}$ were associated with asthma in the present study similar to the previous report. These findings suggest an association of atopy to wheezing in these children [19].

Several studies on SPT using different reagents have been done at different geographical locations with healthy children as well as those with wheezing and allergic diseases. In a study of SPT on 102 children with wheezing or allergic diseases, 61.8\%(63/102) had sensitization to one or more allergen [20]. Skin prick tests were positive in $14 \%$ and $23 \%$ in wheezing infants at six months and 12 months, respectively [21]. We found $20.25 \%$ SPT positivity in our cohort of asthmatic children aged two to 14 years. Another study had reported positivity to at least one allergen in $13.5 \%$ of children [22]. However few studies from India reported higher SPT positivity; Northern India reported 55.6\% (100/180) in children above five years and a study from Mumbai children with allergic rhinitis, wheezing and eczema showed an SPT positivity of 53.2\%.

In the present study, we found the prevalence of SPT positivity is increased significantly with increasing age $(\mathrm{P}=0.001)$. These findings might be attributable to the natural history of atopic disorders (atopic march) where exposure to outdoor allergens occurring in later childhood. This is similar to the observation by AlZayadneh et al. who reported SPT positivity increasing significantly with age [19,23]. Aeroallergen sensitization in wheezing children ( $\mathrm{n}=100$ ) was studied by Pendino et al. and found sensitization to dust mite, pollen, and mold to be $58 \%, 13 \%$, and $8 \%$ respectively [24]. A study from Northern India showed $36.7 \%$ sensitization to housefly antigen and $7.8 \%$ to house dust mite [8]. Our findings were lower (27.5\%) in the dust mite group but higher in the pollen (53.7\%) and mold (45\%) group. This might be due to the inclusion of younger children (six months to 10 years) in the study by Pendino et al. supporting the fact that indoor allergens exposure occurs earlier in childhood $[24,25]$.

The sensitivity of patients to different groups of allergens (pollens, molds, mites, animal dander, foods) is different in different studies. Breborowicz et al. reported most frequent allergy was timothy, house dust mite, birch, mugwort, cat dander and dog dander [22]. We found timothy, dust mite, and Kentucky bluegrass sensitization in about $20 \%$ each with a lower prevalence of mugwort (13.82\%) and cat epithelia (17.5\%) sensitization in our study. Olive tree pollen, cat fur allergen, and house dust mites were the most common inhaled allergens in children from Al-Karak as reported by Al-Zayadneh et al. [19]. Raj et al. reported an SPT positivity to rice grain dust and house dust mite to be $31.1 \%$ and $7.8 \%$, respectively [8]. There is a paucity of data from different parts of India regarding the allergen prevalence and sensitization in childhood asthma and further studies using different allergens in other parts of the country may be useful.

We found a similar positive rate of SPT for mite as compared to Luo et al. (27.5\% vs $24.2 \%$ ) [20]. D. pteronyssinus and D. farinae are the two predominant mites tested in the present study with a positivity rate of 22.5\% and 21.3\%, respectively. Doshi and Tripathi and Al-Zayadneh et al. reported the most predominant mite to be D. pteronyssinus similar to our study [19,23]. However, Luo et al. reported significantly high positivity in SPT for D. farinae as compared to D. pteronyssinus (50.0\% vs. $14.7 \% ; \mathrm{P}<0.05)$ [20].

We found $17.5 \%$ SPT positivity to cow's milk in children with asthma which is much higher than the reported prevalence of cow's milk hypersensitivity $(0.59 \%)$ in a study of 1015 healthy infants aged eight months to 18 months by Kucukosmanoglu et al. [26]. In the study of Kucukosmanoglu et al., the prevalence of egg sensitization based on skin prick test results has been found to be $1.87 \%$ among Turkish healthy infants in Istanbul, which is much lesser than the SPT positivity to hen's egg (18.8\%) in our children [27]. This suggests a higher prevalence of cow's milk allergy and egg allergy in asthmatic children as compared to healthy children.

The key for allergy diagnosis lies in detailed clinical history including periodicity of symptoms (seasonal/perennial, diurnal), temporal association of allergen and symptoms, aggravating and relieving factors, occupational exposure, pet, and insects exposure. The important history of triggers reported by parents was "sleeping/lying in bed," "exercise," and "dust exposure" in 31.9\%, 9.7\%, and 6.9\%, respectively. Most of them (98.8\%) reported diurnal variations and $42.5 \%$ reported seasonal variations. The trigger factors, seasonal and diurnal variations were not predictive of the allergen responsible for the attacks, which might be due to the overlapping of multiple allergens causing symptoms in a particular child. 


\section{Limitation}

The study was conducted in a single center and few selected standardized reagents were tested as per the availability. As the allergy test was restricted to SPT, the results can't exclude non-IgE mediated allergy. However, SPT forms a simple, cost and time-effective tool for the detection of allergic sensitization in childhood asthma specific for a geographical location. It provides a scientific basis for guiding clinicians for the initiation of avoidance of aeroallergens and food restriction.

\section{Conclusions}

Childhood asthma is commonly associated with eosinophilia, increased serum IgE and a significant rate of SPT positivity; suggestive of atopy. Increasing age is significantly associated with increasing SPT positivity. Cow's milk allergy is seen more in females compared to males. The most common sensitive aeroallergens were Kentucky bluegrass and Dermatophagoides pteronyssinus, whereas spinach and banana were the most common food allergen.

\section{Additional Information \\ Disclosures}

Human subjects: Consent was obtained or waived by all participants in this study. Bhima Bhoi Medical College and Hospital issued approval 18/22.3.2019. Animal subjects: All authors have confirmed that this study did not involve animal subjects or tissue. Conflicts of interest: In compliance with the ICMJE uniform disclosure form, all authors declare the following: Payment/services info: All authors have declared that no financial support was received from any organization for the submitted work. Financial relationships: All authors have declared that they have no financial relationships at present or within the previous three years with any organizations that might have an interest in the submitted work. Other relationships: All authors have declared that there are no other relationships or activities that could appear to have influenced the submitted work.

\section{Acknowledgements}

We would like to thank Prof. N. K. Mohakud and Dr. R. R. Das for constantly inspiring us in this work; Dr. Bijayabhusan Nanda, Director, Regional Institute of Planning, Applied Economics and Statistics, Odisha, for providing statistical guidance; and Francis Satapathy for his help in drafting the manuscript.

\section{References}

1. ("New) 2019 GINA report: global strategy for asthma management and prevention . (2019). https://ginasthma.org/reports/2019-gina-report-global-strategy-for-asthma-management-andprevention/\#: : :text=The\%2020....

2. Pearce N, Ait-Khaled N, Beasley R, et al.: Worldwide trends in the prevalence of asthma symptoms: phase III of the International Study of Asthma and Allergies in Childhood (ISAAC). Thorax. 2007, 62:758-766. 10.1136/thx.2006.070169

3. Sembajwe G, Cifuentes M, Tak SW, Kriebel D, Gore R, Punnett L: National income, self-reported wheezing and asthma diagnosis from the World Health Survey. Eur Respir J. 2010, 35:279-286. 10.1183/09031936.00027509

4. Martinez FD, Wright AL, Taussig LM, Holberg CJ, Halonen M, Morgan WJ, The Group Health Medical Associates: Asthma and wheezing in the first six years of life . N Engl J Med. 1995, 332:133-138. 10.1056/NEJM199501193320301

5. Burrows B, Martinez FD, Halonen M, Barbee RA, Cline MG: Association of asthma with serum IgE levels and skin-test reactivity to allergens. N Engl J Med. 1989, 320:271-277. 10.1056/NEJM198902023200502

6. Borish L, Chipps B, Deniz Y, Gujrathi S, Zheng B, Dolan CM, TENOR Study Group: Total serum IgE levels in a large cohort of patients with severe or difficult-to-treat asthma. Ann Allergy Asthma Immunol. 2005, 95:247-253. 10.1016/S1081-1206(10)61221-5

7. Azad MB, Chan-Yeung M, Chan ES, Dytnerski AM, Kozyrskyj AL, Ramsey C, Becker AB: Wheezing patterns in early childhood and the risk of respiratory and allergic diseases in adolescence. JAMA Pediatr. 2016, 170:393-395. 10.1001/jamapediatrics.2015.4127

8. Raj D, Lodha R, Pandey A, Mukherjee A, Agrawal A, Kabra SK, New Delhi Childhood Asthma Study Group: Aeroallergen sensitization in childhood asthmatics in northern India . Indian Pediatr. 2013, 50:1113-1118. 10.1007/s13312-013-0304-9

9. Doherty G, Bush A: Diagnosing respiratory problems in young children. Practitioner. 2007, 251:22-25.

10. Barbee RA, Halonen M, Lebowitz M, Burrows B: Distribution of IgE in a community population sample: correlations with age, sex, and allergen skin test reactivity. J Allergy Clin Immunol. 1981, 68:106-111. 10.1016/0091-6749(81)90167-6

11. Kjellman NM, Johansson SG, Roth A: Serum IgE levels in healthy children quantified by a sandwich technique (PRIST). Clin Allergy. 1976, 6:51-59. 10.1111/j.1365-2222.1976.tb01411.x

12. Faul F, Erdfelder E, Lang AG, Buchner A: G*Power 3: a flexible statistical power analysis program for the social, behavioral, and biomedical sciences. Behav Res Methods. 2007, 39:175-191. 10.3758/bf03193146

13. Rathoria E, Bansal U, Gupta A, Gupta NB, Ahuja R, Rathoria R: Study of serum IgE levels in childhood asthma in Barabanki region, India. Int J Contemp Pediatr. 2018, 5:1755-1758. 10.18203/23493291.ijcp20183369

14. Worldwide variation in prevalence of symptoms of asthma, allergic rhinoconjunctivitis, and atopic eczema: 
ISAAC. The International Study of Asthma and Allergies in Childhood (ISAAC) Steering. Lancet. 1998, 351:1225-1232.

15. Paramesh H: Epidemiology of asthma in India. Indian J Pediatr. 2002, 69:309-312. 10.1007/BF02723216

16. Peng Z: Vaccines targeting IgE in the treatment of asthma and allergy . Hum Vaccin. 2009, 5:302-309. 10.4161/hv.5.5.7442

17. Abraham JT, Barcena MA, Bjelac JA, et al.: Specific diagnostic modalities. Review for the Allergy \& Immunology Boards. Lee G, Stukus D, Yu Joyce (ed): ACAAI, Arlington Heights, IL; 2016. 3rd ed.:417-500.

18. Schimke LF, Sawalle-Belohradsky J, Roesler J, et al.: Diagnostic approach to the hyper-IgE syndromes: immunologic and clinical key findings to differentiate hyper-IgE syndromes from atopic dermatitis. J Allergy Clin Immunol. 2010, 126:611-617. 10.1016/j.jaci.2010.06.029

19. Al-Zayadneh EM, Alnawaiseh NA, Altarawneh AH, et al.: Sensitization to inhaled allergens in asthmatic children in southern Jordan: a cross-sectional study. Multidiscip Respir Med. 2019, 14:37. 10.1186/s40248019-0199-y

20. Luo R, Zhong LL, Yi HL, Tan YP, Chen M, Li Y: Results of skin prick test in young children with wheezing or allergic diseases. [Article in Chinese]. Zhongguo Dang Dai Er Ke Za Zhi. 2012, 14:282-284.

21. Lopez N, de Barros-Mazon S, Vilela MM, Condino Neto A, Ribeiro JD: Are immunoglobulin E levels associated with early wheezing? A prospective study in Brazilian infants. Eur Respir J. 2002, 20:640-645. 10.1183/09031936.02.00219302

22. Breborowicz A, Pieklik H, Burchardt B: Evaluation of the prevalence sensitization to common inhaled allergens in children of school age using skin tests. [Article in Polish]. Pediatr Pol. 1996, 71:11-14.

23. Doshi A, Tripathi DM: Early house dust mite sensitivity in Mumbai children . Indian J Pediatr. 2016, 83:386390. 10.1007/s12098-015-1952-7

24. Pendino P, Agüero C, Cavagnero P, Lopez K, Kriunis I, Molinas J: Aeroallergen sensitization in wheezing children from Rosario, Argentina. World Allergy Organ J. 2011, 4:159-163. 10.1097/WOX.0b013e318232df96

25. Thomsen SF: Epidemiology and natural history of atopic diseases. Eur Clin Respir J. 2015, 2:10.3402/ecrj.v2.24642

26. Kucukosmanoglu E, Yazi D, Yesil O, et al.: Prevalence of immediate hypersensitivity reactions to cow's milk in infants based on skin prick test and questionnaire. Allergol Immunopathol (Madr). 2008, 36:254-258. 10.1016/s0301-0546(08)75219-4

27. Kucukosmanoglu E1, Yazi D, Yesil O, et al.: Prevalence of egg sensitization in Turkish infants based on skin prick test. Allergol Immunopathol (Madr). 2008, 36:141-144. 